\title{
NORFACE
}

MIGRATION

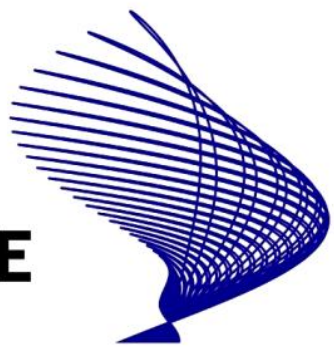

NORFACE MIGRATION Discussion Paper No. 2011-16

\section{Immigration and Wages: Evidence from Construction}

Bernt Bratsberg and Oddbjørn Raaum 
April 2010

\title{
Immigration and Wages: Evidence from Construction*
}

\author{
Bernt Bratsberg and Oddbjørn Raaum \\ Ragnar Frisch Centre for Economic Research, Gaustadalleen 21, 0349 Oslo \\ bernt.bratsberg@,frisch.uio.no / oddbjorn.raaum@,frisch.uio.no
}

\begin{abstract}
To identify relative wage impacts of immigration, we make use of certification and licensing requirements in the Norwegian construction sector that give rise to exogenous variation in immigrant employment shares across trades. Individual panel data reveal substantially lower wage growth for workers in trades with rising immigrant employment than for other workers. Selective attrition from the sector masks the causal wage impact unless accounted for by individual fixed effects. For low and semi-skilled workers, effects of new immigration are comparable for natives and older immigrant cohorts, consistent with perfect substitutability between native and immigrant labor within trade. Finally, we present evidence that immigration reduces price inflation, as price increases over the sample period were significantly lower in activities with growth in the immigrant share than in activities with no or small change in immigrant employment.
\end{abstract}

*We gratefully acknowledge the helpful discussions with and comments of Rolf Andersen, George Borjas, Jon Erik Dølvik, Christian Dustmann, Line Eldring, Steinar Holden, Olav Magnussen, Kalle Moene, Jim Ragan, Stein Reegård, Marianne Røed, Pål Schøne, Sverre Try, Eskil Wadensjö, Heidi Wølneberg, and seminar participants at FAFO; Institute of Social Research; Norwegian School of Economics and Business Administration; University of Oslo; and SOFI, University of Stockholm. We also acknowledge funding from Norface (project \#415), the Norwegian Research Council (grant \#17352/S20), and the Ministries of Finance and Labour (internal project \#1391). This paper is part of the research activities of the centre of Equality, Social Organization, and Performance (ESOP), University of Oslo. Data made available by Statistics Norway have been essential for this research. 


\section{Introduction}

While most developed nations favor policies that facilitate the international movement of goods and capital, they tend to pass legislation that restricts the international mobility of labor. Immigration laws are often controversial, and native attitudes towards immigration will be influenced by their perception of how immigrants affect their labor market opportunities. Immigrants can be expected to compete with native workers with similar skills and place downward pressure on their wages, but other workers may benefit from complementarities as immigrant labor raises the value of their own services. If immigrant inflows lower equilibrium wages, immigration can further be expected to reduce production costs and product prices and, thus, generate surplus for consumers in general (Cortes, 2008). This paper addresses wage and price effects of immigration. As in other impact studies, empirical identification is based on variation in immigration flows across units of the labor market. A fundamental challenge to this approach is to determine counterfactual outcomes. When one observes wages in units where immigrants enter, the impact should be assessed in relation to what would have been the outcome in the absence of immigrant inflows. This counterfactual is typically approximated by observed outcomes in labor market units with different levels of immigration. The challenge is that mobility may cause simple comparisons of labor market units with high and low immigrant shares to be misleading. Immigrants typically locate endogenously according to job opportunities (Borjas, 2001), natives may leave units where immigrants enter (Borjas, 2006), or natives may selectively exit the labor market all together (Card, 2001).

With such challenges to identification, it is of no surprise that the empirical literature offers a wide range of estimates of the wage impact of immigration. Indeed, with an array of both negative and positive estimates at hand, literature reviews and meta analyses tend to conclude that the empirical evidence points to zero or, at most, a small adverse effect of immigration on native wages (Greenwood and McDowell, 1986; Friedberg and Hunt, 1995; Longhi et al, 2005; Okkerse, 2008). In recent years, there has been renewed interest in the labor market consequences of immigration, with added focus on placing empirical estimates in the context of labor demand theory (Card, 2001; 2009; Borjas, 2003; Ottaviano and Peri, 2006; 2008; Manacorda et al, 2007, Borjas et al, 2008). A review of the cited studies reveals considerable disagreement about magnitudes of key parameter estimates and, therefore, the overall economic impact of 
immigration. At the present stage, empirical studies of the wage effect of immigration that build on transparent and convincing identification strategies are likely to make significant contributions to this literature.

In this paper, we study the evolution of wages of workers in the Norwegian construction sector during a period of rising immigrant employment. Although changes in demand conditions over the sample period arguably were similar, changes in immigrant employment turned out very uneven across different segments of the construction sector. Requirements in certain activities regarding certification and authorization of skills according to national standards made it difficult for new immigrants to enter some segments (e.g., electrical installation and plumbing companies) but not others (e.g., carpenter and painting firms). In this study, we treat such licensing requirements as a source of exogenous variation. In the context of counterfactuals, conditional wage growth in segments with strict licensing requirements and no immigrant employment growth can be used to gauge what would have happened in other segments had the increase in immigrant labor supply not taken place. Thus, our focus on a relatively narrow sector of the economy where demand conditions move together across segments, paired with exogenous variation in change in the immigrant employment rate across activities with and without licensing requirements, gives rise to plausible identification of the wage effect of immigration - and is a major contribution of the paper.

A second contribution is that we exploit individual longitudinal data, which turns out essential in the empirical analysis. Panel data allow us to account for unobserved individual components of wages, and we find that individual wage growth over the period was substantially lower for workers who faced increases in the immigrant employment share than for other workers. Difference-in-difference-in-difference estimates, where we draw on wage growth of workers with construction vocations but employed outside the building industry, show that the finding is not driven by differential wage trends across vocations. We also find that immigration is associated with exit of low-wage workers from the sector. The systematic sorting of low-wage workers out of activities with growing immigrant employment leads to a spurious positive correlation between immigration and native wages in the data. An important empirical result is that this correlation masks the underlying negative effect of immigration on individual wages. The longitudinal data also reveal that, five years after exiting the sector, one third of the (working- 
aged) leavers received some form of public welfare benefits, and that benefit uptake correlates positively with the immigrant share. Selective attrition stems in part from workers leaving the labor market.

A third contribution is that we move beyond merely studying the effect of immigration on wages and examine whether increased immigration also affects product prices. In this, we follow up on recent studies of immigration and prices, such as Lach (2007) and Cortes (2008), and show that price increases within the construction sector were significantly lower for services that saw large increases in immigrant employment than for services with no or small changes in the immigrant employment share. In fact, our data indicate that the direct cost reductions associated with use of immigrant labor and the indirect reductions through their impact on native wages combine to produce relative price effects that are even larger in size than the relative wage adjustments.

In the literature, a competitive labor market with demand derived from a multilevel CES technology has become the standard theoretical framework for interpreting the relationship between immigration and the wage structure. ${ }^{1}$ This framework provides guidance for empirical assessment of parameters of the demand structure based on developments of relative wages and employment of immigrants and natives, and prior studies typically make inference about technology parameters from aggregated data. Our finding that compositional change of the native workforce correlates with change in immigrant employment raises important concerns about use of aggregated data for this purpose. Instead, we derive and estimate micro-level wage equations, accounting for individual fixed effects. Empirical results suggest that immigrant and native labor are close to perfect substitutes within construction activities, particularly for low and semi-skilled workers. This follows from our finding that, for workers with low and medium educational attainment, an increase in the immigrant employment share has the same wage reducing effect for earlier immigrant cohorts as for native workers.

Our findings underscore that, in the economic analysis of consequences of immigration, there are winners and losers. While native workers directly affected by immigrant inflows face reduced wage growth and possible disemployment, the price dampening effect of immigrant construction

\footnotetext{
${ }^{1}$ Borjas (2009) formalizes the approach in a comprehensive theoretical framework where the wage impact of immigration depends on such factors as the elasticity of product demand, the rate at which immigrants expand the consumer base, the elasticity of supply of capital, and the elasticity of substitution across inputs of production.
} 
labor points to direct benefits for a large consumer base and considerable gains in consumer's surplus. Depending on the composition of immigrant inflows, costs and benefits will be unevenly distributed across groups of natives. By focusing on one sector of the economy, we may overlook other important impacts of immigration. But, the major advantage of this focus is that it gives us credible identification of substitution parameters and relative wage and price effects. And given the present state of an empirical literature marked by controversy, such identification takes the debate one step further.

\section{Background}

Immigration gives rise to a positive shift in labor supply and standard neoclassical theory specifies under what conditions wages of incumbent workers adjust in response. In a competitive labor market with homogeneous labor, the wage will decline if the labor demand curve is downward sloping (Borjas, 2003). With heterogeneous labor, increased use of one type of labor due to a reduced wage may change the demand for other types depending on the degree of substitutability or complementarity with the more abundant type (Ottaviano and Peri, 2006). Such demand changes may in turn alter wages even for workers not directly affected by immigration. Further, investment responses to changes in the return to physical capital will affect the equilibrium wage structure in the long run (Peri, 2008). As often is the case, theory does not unambiguously predict how the wage structure will be affected by immigration. As we will illustrate in Section 6, the wage impact of immigration for native workers will depend on the skill composition of immigrants and the substitutability between immigrant and native labor (within skill group) as well as the degree of substitution between workers with different qualifications.

Contributions in the empirical literature studying the impact of immigration on the wage structure use various identification strategies. Studies also differ with respect to the type of wage effects they aim at. One major strand of the literature seeks to identify the direct effect on wages of native workers experiencing immigration-induced increases in labor supply. Identification is feasible due to variation in the immigrant share across labor market units. When it comes to definition of units or groups, classification based on geography or skill/occupation dominates. Studies using spatial variation (e.g., Borjas, 1987; Altonji and Card, 1991; Card, 2001; 2005; LaLonde and Topel, 1991; Pischke and Velling, 1997; Dustmann et al, 2005; 2007) face two 
important challenges to identification. Immigrants tend to move into regions where job opportunities are favorable and natives may selectively move out as immigrants enter. Instruments like the lagged immigrant stock motivated by chain migration or network effects may help identification, but, as pointed out by Card (2001), even predicted immigrant shares may correlate with present labor market conditions if regional or group-specific shocks are highly persistent.

To overcome the problem of endogenous location, some studies explore particular events that arguably generate exogenous shocks in labor supply. Examples include the 1980 arrival of Cuban immigrants on a flotilla of privately chartered boats from Mariel to Miami (Card, 1990); the repatriation to France of Algerians of European origin prompted by independence in 1962 (Hunt, 1992); the return of Portuguese colonialists during the mid 1970s after the takeovers in Angola and Mozambique (Carrington and DeLima, 1996); and the lifting of emigration restrictions in the Soviet Union that led to huge immigrant flows of Russian Jews into Israel in the early 1990s (Friedberg, 2001). A drawback of the natural experiment identification strategy is the limited numbers of independent observations they generate.

Endogenous location has led some researchers to focus on variation in immigration inflow rates over time within groups defined at the national level (Borjas 2003; Aydemir and Borjas, 2007). At the national level, the immigrant share among, say, those with less than 12 years of schooling and 6-10 years of work experience, will not be affected by internal migration. However, withdrawal from the labor market or out- (or re-)migration may cause violation of the conditional independence assumption as wages are observed only for workers actually employed. Still, labor market entry and exit are presumably less responsive to wage determinants than mobility across regions within the host country. Estimates based on national level variation will be biased, though, if the group-specific wage trends caused by other factors (like technical change) correlate with changes in the immigrant share over time. As noted by Borjas (2003, p.1362) and Card (2005, p. F316), assumptions about others drivers of labor demand are also needed. For example, to attribute any part of the drop in the relative wages of low-skilled US workers during the 1980s to immigration, one must make assumptions about how skill biased technical change alters relative demand. 
Changes in relative wages and labor supply across skill groups, and between immigrants and natives within skill group, can be used to identify underlying parameters of labor demand. An influential strand of literature makes use of structural models, typically building on a CES technology that allows for imperfect substitution between workers with different skills as well as between immigrants and natives within skill group. In this literature, average wage regressions identify the critical elasticities of substitution. Knowing these elasticities and relative productivity parameters, one might back out the wage effects of immigration-induced increases in labor supply; see e.g., section VII of Borjas (2003), Ottaviano and Peri (2006), and Manacorda et al (2007).

The wage adjustments for native workers following an immigration-induced shift in labor supply will depend on the substitutability of labor across types, with small wage adjustments when it is easy to substitute the more abundant factor for other types. Further, native wage adjustments are less responsive to immigration when immigrants and natives are imperfect substitutes. With imperfect substitutability, a larger part of the wage adjustment will be absorbed by immigrants who arrived earlier (who typically are closer substitutes with newly arrived immigrants). As pointed out by Manacorda et al., imperfect substitutability can explain the apparent puzzle that supply shocks from expansions of higher education seem to alter relative wages of skilled workers (Katz and Murphy, 1992), while many studies find only minor impacts of increased labor supply from immigration.

\section{Empirical Model}

We consider an empirical model where the log wage of (for now) native worker $i$ in group (or labor market unit) $j$ in year $t$ reads

$$
\ln W_{i j t}=\theta f\left(P_{j t}\right)+\beta^{\prime} X_{i t}+\gamma_{j}+\tau_{t}+u_{i}+\varepsilon_{i j t},
$$

where $P_{j t}$ is the immigrant employment share in group $j$ at time $t, X_{i t}$ represents individual wage determinants such as (a third-order polynomial of) age, gender, and educational attainment, $\gamma_{j}$ denotes the group fixed effect, $\tau_{t}$ the period effect (i.e., the coefficient of a year dummy), $u_{i}$ a fixed individual error component, and $\varepsilon_{i j t}$ captures remaining factors including transitory wage 
components. The functional form, $f$, is motivated by a nested CES framework (see Section 6 ) and reads $^{2}$

$$
f\left(P_{j t}\right)=\ln \left(\frac{1}{1-P_{j t}}\right)=\ln \left(1+\frac{M_{j t}}{N_{j t}}\right),
$$

where $M$ and $N$ denote immigrant and native employment, respectively. It follows that the direct effect of a change in relative immigrant employment on the native wage can be written ${ }^{3}$

$$
\frac{\partial \ln W_{j t}}{\partial\left(M_{j t} / N_{j t}\right)}=\theta\left(1-P_{j t}\right)
$$

Likewise, the elasticity of the native wage with respect to the size of the immigrant stock is

$$
\frac{\partial \ln W_{j t}}{\partial \ln M_{j t}}=\theta P_{j t}
$$

Note that the specification in equation (1) captures the direct, within-group effect of (changes in) immigrant employment only, as an identifying restriction of the model is that an increase in $P_{j t}$ does not affect wages of workers in groups other than $j$. Therefore, our approach follows the strand of the literature seeking to estimate the effect of immigration on the relative wages of workers directly impacted by foreign labor. As we discuss in Section 6, in a competitive labor market wage effects will reflect movements along the labor demand curve and the estimated parameters of wage equations for natives and immigrants can be interpreted as (combinations of) underlying technology parameters. With these parameters at hand, the direct as well as indirect effects on the wage structure can be simulated (see, e.g., Part VII of Borjas, 2003).

Empirical identification of our parameter of interest, $\theta$, requires within-group variation in the immigrant share that is uncorrelated with unobserved wage determinants;

\footnotetext{
${ }^{2}$ As we show in Section 6, with a nested CES technology and under certain assumptions, the coefficient $\theta$ will equal the negative of $(1-\rho / \pi)$ where $\rho$ reflects substitution between groups and $\pi$ substitution between immigrant and native labor within group.

${ }^{3}$ This is the impact metric favored by Borjas (2003). Another metric commonly used in the literature is $\partial \ln W_{j t} / \partial P_{j t}$, which in our specification is given by $\theta /\left(1-P_{j t}\right)$.
} 
$\operatorname{cov}\left(P_{j t}, \varepsilon_{i j t} \mid X_{i j t}, \gamma_{j}, \tau_{t}, u_{i}\right)=0$. That is, factors causing variation in $P_{j t}$ must be orthogonal to the transitory unobserved wage determinants of group $j$ in year $t$. A number of mechanisms might cause violation of this conditional independence assumption. ${ }^{4}$ At the national level, net migration flows will be influenced by the state of the labor market with high immigration rates under favorable labor market conditions. If such conditions are shared across the economy, aggregate national factors will be accounted for with time fixed effects (as do we in the present study). Of greater concern are differential trends in economic conditions across units of the labor market. Because immigrants seek out segments of the economy with favorable job opportunities, impact studies that fail to control for differential trends may be contaminated by a positive correlation between demand conditions and immigrant employment. In the spirit of natural experiments, identification is more reliable if the data contain sources of exogenous variation across groups to back the conditional independence assumption. In this paper, we exploit certification requirements that generate exogenous variation in immigrant inflows across activities of the construction sector. The set-up also permits testing of the equal-trends assumption with a difference-in-difference-in-difference approach, where we gauge vocation-specific wage trends from the wage growth of workers with the exact same vocational background but employed outside the construction sector.

Another concern is native mobility. First, if native workers move out of groups as immigrants move in, native mobility might counteract the shift in labor supply (there remains disagreement over the empirical importance of this; see, e.g., Card, 2001, and Borjas, 2006). The implication of native response-migration will be amplified if native mobility contains an element of selfselection related to unobserved wage determinants. For example, if it is the lowest paid natives who leave, those who remain will be positively selected causing a correlation between immigration and native wages and a positive bias in estimates of the direct effect of immigration on wages. Finally, wages are only observed for those who work. If immigrant employment crowds out natives disproportionally in the bottom of the wage distribution, or if immigrants replace natives perhaps worn out by physically demanding jobs and on their way onto disability, parameter estimates will suffer from selectivity bias unless the estimator accounts for selective

\footnotetext{
${ }^{4}$ Note that the vast majority of studies in the relevant literature apply the conditional independence assumption without being able to condition on $u_{i}$; i.e, they make the stronger assumption, $\operatorname{cov}\left(P_{j t},\left(\varepsilon_{i j t}+u_{i}\right) \mid X_{i j t}, \gamma_{j}, \tau_{t}\right)=0$.
} 
attrition among natives. With longitudinal, individual data we are able to control for individual fixed effects $\left(u_{i}\right)$.The following data section explains why our data with longitudinal observations of workers across activities in the Norwegian construction sector provide a plausible case for identification.

\section{Data and Institutions}

Our empirical focus is the wages of workers employed in construction-sector firms during the eight-year period 1998 through 2005. The wage data are based on administrative payroll records submitted by employers to tax authorities, where each record includes both a personal identifier for the worker and a firm identifier. We use the firm identifier to give the worker an industry affiliation (i.e., a NACE classification), collected from registers of establishments with each unit uniquely classified by Statistics Norway according to the firm's own description of its main activity. From the payroll register, we first extracted every pay record in mainland firms with a construction-sector affiliation (i.e., a two-digit NACE code of 45). For each individual and year, we kept the pay record for the 'main' job, as defined by working hours (full vs. part time), duration of the contract, and total pay. Next, we linked information on immigrant status drawn from the central population register to the pay record by means of the personal identifier. ${ }^{5}$ Finally, we used the main-job payroll record to form the dependent variable of the wage regression. Ideally, we would have liked to know the worker's baseline hourly wage, but the pay record gives hours worked in three broad brackets only (two part time and a full time bracket). Instead, we constructed a daily wage by dividing total pay on the number of days of the employment contract. To reduce the influence of measurement issues related to variation in hours worked, we restrict the samples underlying wage regressions to full-time employees.

In the gross sample, there are between 174,000 and 181,000 observations of native-born construction workers each year. The top panel of Figure 1 illustrates developments in native and

\footnotetext{
${ }^{5}$ For one half of the immigrants in the construction-sector payroll data, immigrant status is determined from the socalled "D-number" attached to the payroll record. A foreign-born person who appears in the payroll register will be issued a D-number by authorities when not a current or former registered resident of Norway. For foreign construction workers, non-inclusion in the population register typically means that they maintain a primary residence abroad while working in Norway. The large share without residency hints that that the positive shifts in product demand normally associated with large population movements may be smaller for immigrant construction labor than for other immigrant groups.
} 
Figure 1: Immigrant and native construction employment and housing starts, 1998-2005

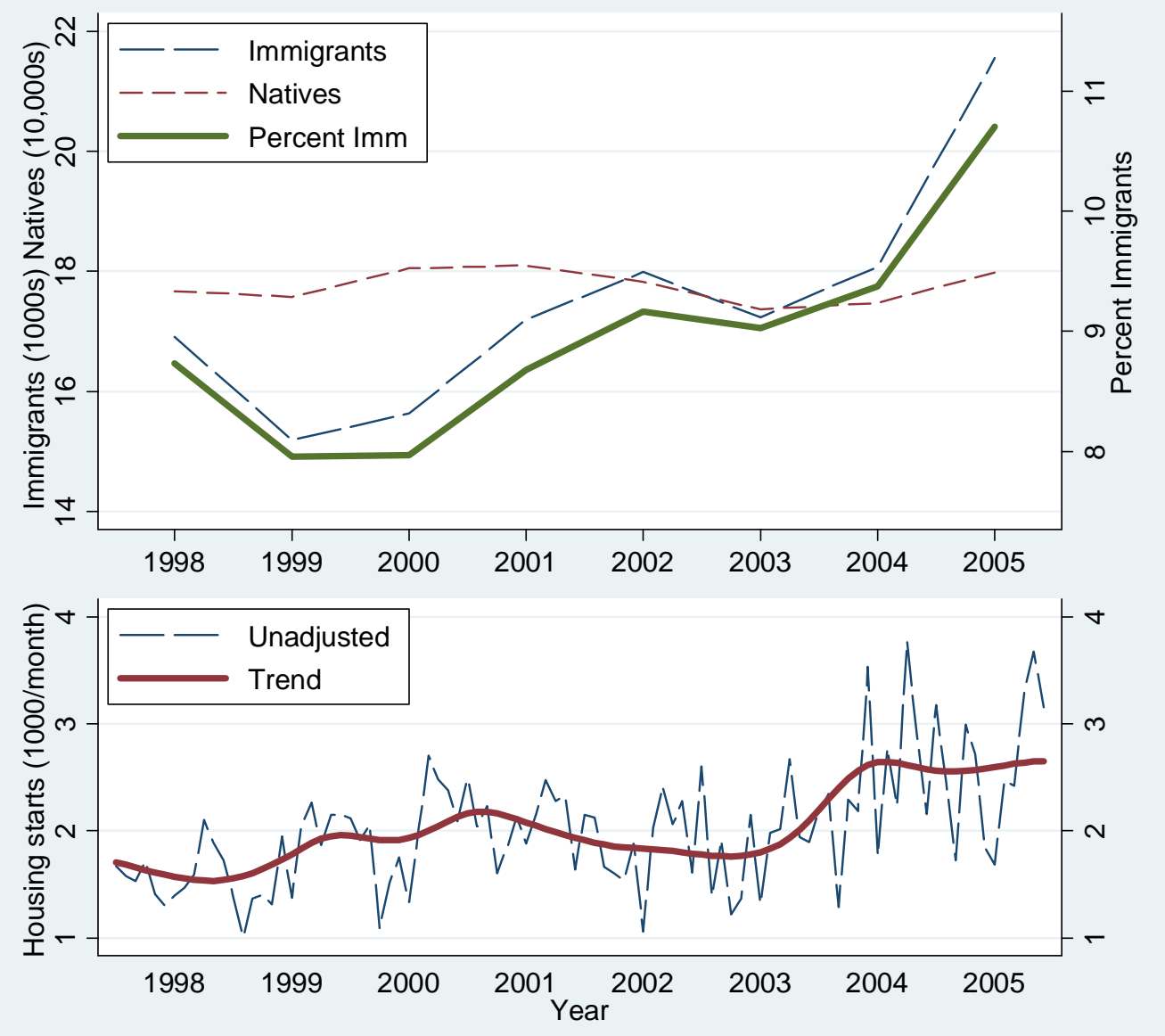

Source: Own tabulations from register data (top panel) and Statistics Norway (bottom panel; see http://www.ssb.no/english/subjects/10/09/byggeareal_en/)

immigrant employment, as well as the immigrant share, for the whole construction sector over the sample period. The bottom panel displays the concurrent cycles of the building industry, represented by monthly housing starts. The panels show that immigrant construction employment fluctuates with building cycles, with total immigrant employment varying between 15,000 (eight percent) in 1999 and 22,000 (11 percent of construction-sector workers) in 2005. But the trends in immigrant employment also reflect factors outside the nation's borders. Immigrant construction employment in Norway draws heavily on two source countries: Sweden and Poland (Berge et al., 2007). Between 1992 and 1997 the Swedish building industry went through a severe downturn, with new housing construction plummeting by more than three quarters 
(Statistics Sweden, 2010). In result, large numbers of Swedish construction workers found jobs in the Norwegian construction sector. Over our sample period, the Swedish construction industry recovered rapidly (e.g., new housing construction increased by 152\% between 1998 and 2005), explaining the initial decline in immigrant employment in Figure 1. The growth in immigrant employment since 2000 stems largely from inflows of workers from Poland and the Baltic states. In particular, the 2004 expansion of the European Union represents an important exogenous shift in aggregate supply of immigrant workers to the Norwegian construction sector.

From the payroll data, we aggregate workers into sixteen separate activities on the basis of the employer's five-digit NACE code. ${ }^{6}$ For each year we define the immigrant employment share,

$$
P_{j t}=\frac{M_{j t}}{M_{j t}+N_{j t}}
$$

where $M_{j t}$ and $N_{j t}$ again denote immigrant and native employment levels in activity $j$ in year $t$. Figure 2 details the activity classification in the data and illustrates that the fraction of immigrant workers varies significantly across activities and time. The figure plots the average annual change in the immigrant employment share over the sample period against the initial share for each of the sixteen activities. Immigrant shares are particularly low in electrical installation, road construction, and machine rentals, reflecting licensing and skill (certification) requirements in these activities. For example, in order to practice as an electrician in Norway a worker must hold a certificate issued by the Directorate for Civil Protection and Emergency Planning. To obtain this certificate, foreign-born workers must pass tests that they possess qualifications sufficient to perform tasks that meet installation standards set by the directorate. ${ }^{7}$ For machine rentals and road construction, immigrant workers typically lack the licenses required to operate heavy machinery and equipment that are demanded by employers.

\footnotetext{
${ }^{6}$ Note that we classify construction activities according to industry, not occupation. The chief reason is that the employer NACE classification was consistently recorded over the sample period. Since 2003, the payroll records also include an occupation code (submitted by the personnel office at the workplace). For those with both an industry and an occupation code, the two series show considerable agreement. To illustrate, $73 \%$ of employees in electrical installation companies are electricians, $60 \%$ of those in plumbing firms are plumbers, and $79 \%$ of employees in painting and carpenter services are painters and carpenters, respectively.

${ }^{7}$ Certified electricians from the neighboring Nordic countries are exempt from these requirements. The construction sectors of the neighboring countries experienced significant booms that coincided with that in Norway (see above), which may explain the lack of an influx of Nordic electricians during our data window.
} 
Figure 2: Immigrant share in 1998 and average annual change between 1998 and 2005

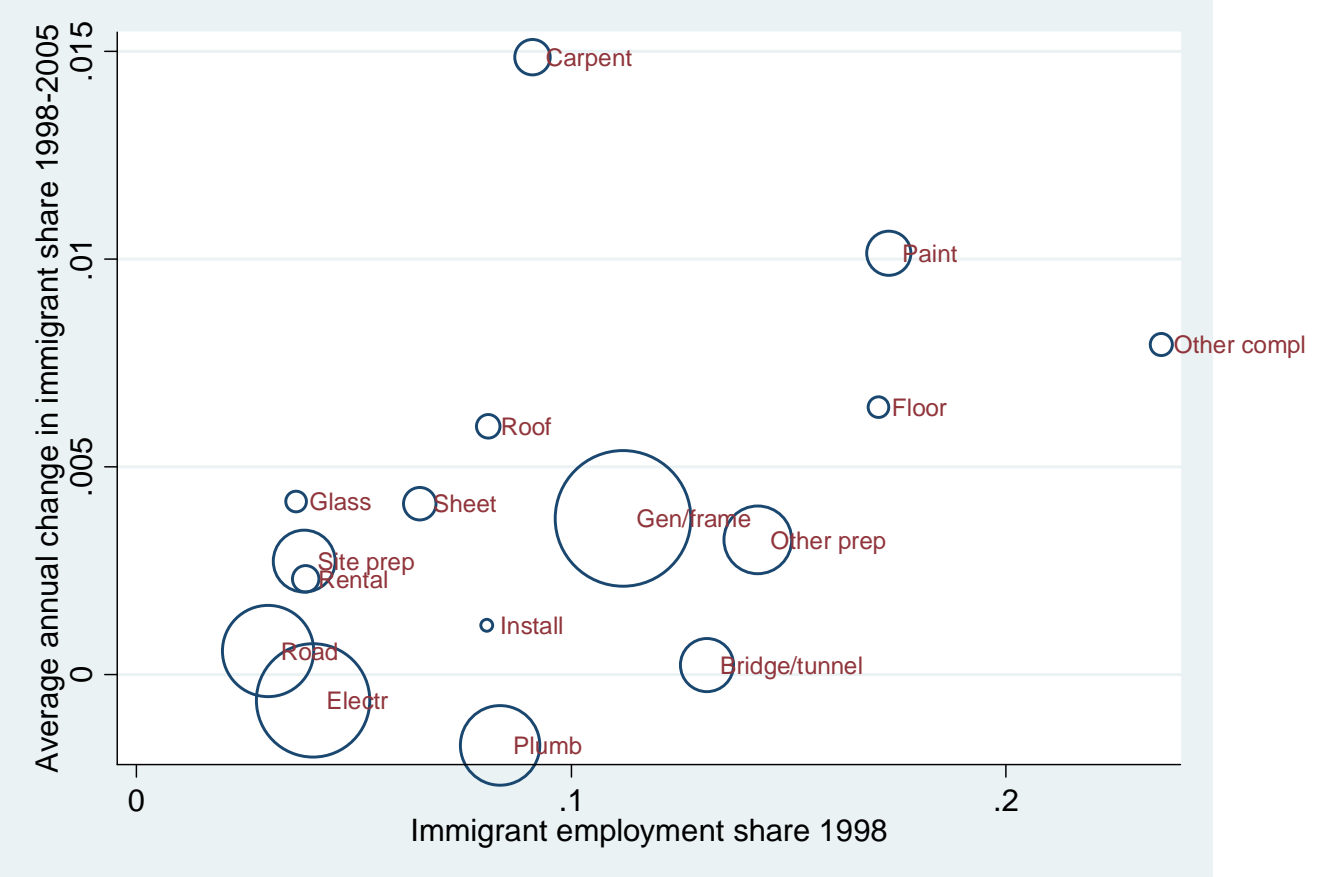

Note: Scatter points are weighted by native employment.

In our empirical analysis, identification of the effect of immigration on wages comes from differential variation in the immigrant share over time across groups. As Figure 2 also shows, there is considerable variation in immigrant employment change in our data. Over the sample period there was hardly any change in immigrant employment in activities with licensing and certification requirements, such as electrical installation, plumbing, road, and bridge and tunnel construction. Immigrant employment in carpenter and painting firms, on the other hand, experienced substantial growth, at a rate of more than one percentage point of the workforce per year. In fact, over the eight-year sample period, the immigrant share increased by 50 percent in painting firms and doubled in carpenter firms. In short, our estimate of the impact of immigration on wages will rely heavily on the wage growth of carpenters and painters relative to electricians, plumbers, and road construction workers.

A critical concern is that the "barriers to entry" in the electrical installation and plumbing trades also apply to natives and that we will falsely attribute low wage growth in certain activities during a construction boom to immigrant inflows when in truth the source is variation in native 
inflows across activities. As we return to in Section 5.2, in a typical year there are as many certified native electricians employed outside as within the construction sector. During a construction boom, these already certificated electricians are free to seek employment in construction. In fact, in 2005 (which followed a significant boom, as Figure 1 shows) among natives with a vocational diploma who were employed in their relevant activity, 23 percent of electricians and 21 percent of plumbers had recent employment outside the construction sector compared to 16 percent of carpenters and 15 percent of painters. At least in the short run, certification requirements inhibit immigrant mobility more than native mobility. ${ }^{8}$

There are at least three sources of measurement error in our immigrant employment share variable. First, because we rely on registered employment contracts, we will not capture individuals who solely work off the books. If such (i.e., full-time) off-the-books employment is more likely in the immigrant population, our measure will understate the true immigrant employment share in the sector. Moreover, if unregistered employment is more common in activities with high immigrant employment shares, our measure might simply proxy for competition from off-the-books employment (rather than competition from immigrant employment). Survey evidence presented in Barth and Ognedal (2008) shows, however, a marked reduction over time in non-reported income in Norway (including the construction sector). ${ }^{9}$ Because our identification draws on the rise in the immigrant employment as illustrated in Figures 1-2, any measured effect on wages is unlikely to simply reflect competition from off-thebooks employment.

A second source of error is that of service mobility, i.e., workers who are posted in the Norwegian construction sector by foreign contractors. Because posted workers typically are paid in the home country of the contractor, they will not be included in the Norwegian payroll data. In recent years, there has been a marked increase in posted workers in Norway, particularly from Eastern Europe. Growth in service mobility is unlikely to have influenced wages in the

\footnotetext{
${ }^{8}$ Long-run equilibrium wage differentials linked to certification and licensing restrictions will be captured by the activity fixed effects in our empirical model.

${ }^{9}$ Unpublished tabulations provided by Erling Barth shows that the fraction of construction workers with nonreported sources of income during the past 12 months declined from two thirds to less than one third between 1980 and 2003.
} 
construction sector during the time interval studied, however, as the sharp rise took place after our sample period (Dølvik and Eldring, 2008).

Third, our immigrant counts fail to consider foreign construction workers formally employed by temporary employment agencies. Especially following the 2004 EU expansion, many foreign workers were recruited by Norwegian temp agencies and hired out to construction companies (Dølvik et al, 2006). As such, our immigrant measure will again understate the true share among construction workers. The payroll data provide some guidance as to the magnitude of this error. When we consider the 97,508 individuals identified in the payroll data as employed by temp agencies (NACE2002 code of 74502) in 2003 or 2004, almost five percent $(4,787)$ later turn up in the data as employed by a construction company, illustrating a close connection between the two industries. While a fair number of those moving between the two industries are immigrants, many native workers also make this job transition (26 percent of the industry switchers are immigrants). Moreover, among switchers the distribution of immigrants and natives across construction activities largely mirrors the distribution captured by our original counts from payroll data. In fact, when we add industry switchers to the construction employment counts from the 2004 payroll data and recalculate activity-specific immigrant employment shares, the new and old data series have a correlation coefficient of 0.99 .

In sum, while the three sources of error in our key explanatory variable are unlikely to cause omitted-variable bias, all three sources might lead to systematic undercounting of immigrant workers and therefore impart bias related to scaling of the immigrant employment measure. If the undercount of immigrant workers is proportional to the true number, the estimate of the effect of immigration on wages will be off by a related factor. To illustrate, suppose the true number of immigrant workers in Norwegian construction is 50 percent higher than that included in payroll data (so that the true immigrant-to-native employment ratio towards the end of the sample period was 0.15 rather than 0.10 ; see Figure 1). Some algebra shows that in this case we would overstate the impact of immigration on wages and that the true parameter $\theta$ will be 70 percent of that based on observed counts. ${ }^{10}$ For this reason, in the next section we also report the elasticity of wages

\footnotetext{
${ }^{10}$ Suppose the observed immigrant count is proportional by a factor $\alpha$ to the true count, $\tilde{M}=\alpha M$. The relationship between the true parameter value $(\theta)$, i.e., the coefficient of equation (1) when the regressor is the true
} 
with respect to the immigrant stock, as this metric will be invariant to any proportional undercount in the immigrant employment share.

\section{Results}

\subsection{The Effect of Immigration on the Native Wage}

We estimate equation (1) based on a sample of construction workers aged 18-60 with full time employment. The dependent variable is the log daily pay and the individual wage determinants $\left(X_{i t}\right)$ include a cubic age polynomial, years of schooling, and gender. In addition, all regressions include fixed effects for each of the 16 detailed construction activities and each of the eight years of observation. Ignoring individual fixed effects $\left(u_{i}\right)$, the estimate of $\theta$ is statistically insignificant and close to zero, see Table 1, column (1). In other words, the conventional approach-which accounts for group fixed effects but fails to consider any correlation between unobserved individual wage determinants and within-group change in the immigrant share - points to no impact of immigration on the wages of Norwegian construction workers.

Including individual fixed effects, as in column (2), makes a large difference for the coefficient estimate, however, and the estimate of $\theta$ is now negative, -0.72 , and statistically significant. Evaluated at the mean immigrant employment share in the native wage sample (0.085), the implied elasticity of native wages with respect to immigration is -0.06 . If immigrant employment increases by ten percent, wages of natives are predicted to fall by 0.6 percent. The -0.06 figure is identical to the immigration wage effect of Borjas (2003), if we evaluate his preferred estimate (p. 1348) at an immigrant share of 0.125 , corresponding to the foreign-born share of the U.S. labor force in 2000 (U.S. Census Bureau, 2009). An advantage of the elasticity just cited is that it is invariant to the problem of systematic undercounts of immigrant employment. In the literature, two more frequently used metrics for the immigrant impact are the derivates of log wages with respect to (1) the immigrant employment share, $\partial \ln W / \partial P$, and (2) relative immigrant employment, $\partial \ln W / \partial(M / N)$. Using the conversions listed in Section 3, our implied estimate of

count, and that based on the observed count $(\tilde{\theta})$ will be given by $\theta=\tilde{\theta} \alpha(1+m) /(1+\alpha m)$, where $m$ denotes the true immigrant-to-native employment ratio. 
Table 1: Impact of immigration on the native log wage

(1)

$$
\begin{aligned}
& \begin{array}{l}
\text { Coefficient of } \\
\ln (1+\mathrm{M} / \mathrm{N})
\end{array} \\
& \begin{array}{l}
\text { Observations } \\
\text { Individuals }
\end{array} \\
& \text { Fixed individual } \\
& \text { effects? }
\end{aligned}
$$

Comment
(2)

(3)

(4)

(5)

(6)

$\begin{array}{llll}-.554 & -.570 & -.032 & -.569 \\ (.175) & (.183) & (.175) & (.180)\end{array}$

$-.103$

(.162)

$-.724$

(.202)

918,082

918,082

217,151

No $\quad$ Yes

Full sample
$296,152 \quad 296,152$

37,019

843,567

840,747

No

Yes

No

No

Balanced panel

Same activity
Drop entrants

Note: Standard errors are reported in parentheses and are clustered within activity-by-year observations. Sample in columns (3) and (4) is restricted to individuals who are included in the wage sample all eight years and who remain employed in the same activity all eight years. Regressions control for age (third order polynomial), years of schooling, gender, activity, and year of observation.

$\partial \ln W / \partial P$ is $-0.724 /(1-0.085)=-0.791$, while $\partial \ln W / \partial(M / N)$ equals $-0.724 *(1-0.085)=-0.662$.

These metrics are, however, quite sensitive to undercounts of immigrant employment. To illustrate, if actual immigrant employment is 50 percent higher than that observed in payroll data, the -0.662 figure will also overstate the true impact by 50 percent. In this case, our parameter estimate implies an elasticity with respect to relative immigrant employment of -0.44 , which is very close to the equivalent elasticity estimate of -0.40 cited by Borjas $(2003$, p. 1349).

Taken together, the results in columns (1) and (2) demonstrate that the conventional estimator is biased towards zero, in line with what is frequently argued for spatial correlation studies. Stated differently, in the full sample of native construction workers there must be a correlation between the individual error component and within-activity variation in the immigrant employment share. As pointed out by Card (2001, p. 53), selection bias may arise when immigrant inflows affect the employment rate of native workers and thereby alter the group of workers for whom we observe wages. The balanced-panel analyses in columns (3) and (4) help us understand how selective participation influences our estimates. The balanced panel consists of native workers with a valid wage observation in all eight years and who were employed in the same activity throughout the sample period. Without individual fixed effects, the coefficient estimate is -0.55 (standard error 
equals 0.18 ) which is not very far from the fixed-effects estimate in column (2). Unlike in the full sample, introducing individual fixed effects has no impact whatsoever on the coefficient estimate as it changes to $-0.57(0.18)$. Therefore, sample inclusion of workers who were employed in the sector for some years only creates a substantial positive correlation between the immigrant share and the unobserved individual wage component. Both newcomers and leavers may potentially contribute to this correlation. These alternative explanations are explored in columns (5) and (6). When we drop entrants - workers who did not hold a construction job during the first half of the sample period, but entered the sector after 2001- the estimate in column (5) is close to zero and of the same magnitude as that of the full sample. Dropping leavers - workers who were present in the data during the first half of the sample period and who ended their construction job before 2002 - on the other hand, yields a coefficient estimate of - $0.57(0.18)$ which is remarkably close to the balanced-panel result as well as that from the full sample when the regression includes individual fixed effects. Although leavers account for less than ten percent of the observations in the full sample, their attrition from the data creates a considerable selection bias in the conventional estimator. As immigrant employment increases within a construction activity, the natives who leave tend to be low-paid workers. Consequently, the stayers represent a positively selected group, rendering a positive correlation between the immigrant employment share and the individual wage component.

Figure 3 illustrates how such compositional change influences observed wage growth over the sample period, especially in activities with rising immigrant employment. The figure plots the (unadjusted) annual growth in average native wages against the annual change in the immigrant share within each activity. The left hand panel shows the observed annual wage change for the full sample, and the right hand panel average wage growth after we exclude leavers. Consider painters. As seen from the left-hand panel, the average (nominal) pay of natives employed by painting firms increased by 3.7 percent annually over the period. A substantial portion of this apparent wage inflation is, however, an artifact resulting from low-paid native painters leaving the sector. When we exclude leavers from the sample, average wage growth for painters who remained was only 2.7 percent per year (see right hand panel). In general, for activities with large increases in immigrant employment, such as painting, carpenter services, flooring, and roofing, annual wage growth is reduced by one third (about one percentage point) when we exclude workers who left the sector before 2001. Conversely, for electrical installation and 
Figure 3: Change in immigrant share and annual wage growth, 1998 - 2005

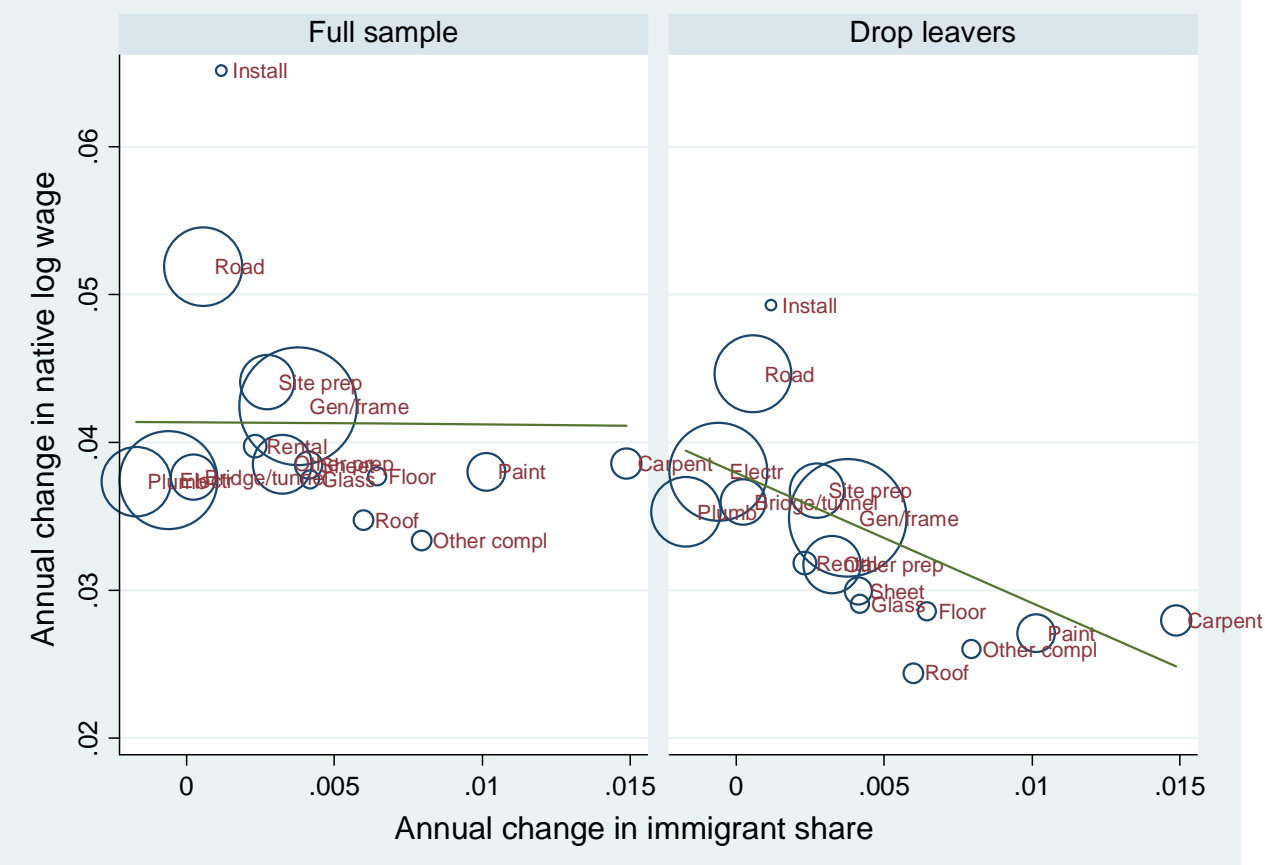

plumbing - activities that saw little change in the immigrant share - there is hardly any difference in average wage growth if we exclude leavers. As is evident from the figure, the regression line relating wage growth to changes in the immigrant share is highly sensitive to whether or not we include leavers in the sample, paralleling the results presented in Table 1. ${ }^{11}$

\subsection{Confounding Factors or Differential Trends?}

In our empirical specification, estimation of the parameter of interest relies on change in the immigrant share within activity over time. Because the specification includes individual characteristics and fixed individual effects, we account for within-activity change in the composition of the native workforce. But, as the immigrant employment measure is the only variable in the model with time variation at the activity level, our estimate will also capture any impact of change in wage determinants correlated with change in the immigrant share. In this section, we first examine whether our key estimate might be sensitive to three such potential

\footnotetext{
${ }^{11}$ The slopes (and standard errors) of the weighted regression lines fitted through the 16 scatter points in each of the two panels of Figure 3 are $-.02(.41)$ and $-.88(.29)$, respectively.
} 
developments at the activity level, as well as sample inclusion of road, tunnel, and bridge construction companies. Next we focus on narrowly defined vocations and account for occupation-specific wage trends by augmenting the sample with workers with construction vocations but employed in other industries. Results are presented in Table 2.

One concern is that immigration affects hours worked of native workers. Because our dependent variable is based on the daily wage, variation in hours worked might lead us to overstate the effect on wages. For example, pressures to work overtime hours during a boom may be stronger in activities where immigrants cannot enter, causing a negative correlation between hours and immigration in the data. The second sensitivity check relates to skill biased technical change (SBTC). If immigrants are more likely to enter (manual) occupations with few formal skill requirements, we might over time observe increases in immigrant employment in activities that lag behind economy-wide wage developments due to SBTC. Third, there is a great deal of variation in industrial relations and wage setting institutions across activities in the construction sector. While three-quarters of road construction workers are members of a trade union, only 10 percent of carpenters are organized. Moreover, there is a substantial negative correlation between union membership and the immigrant employment share in our data (the correlation coefficient is -0.54). This raises the question of whether the immigrant share might proxy for union power, and that the estimated effect of immigration in truth reflects a weakened union bargaining position.

To account for such plausible confounding factors, in Table (2), column (1), we add three variables measuring the propensity to work overtime hours, ${ }^{12}$ the share of skilled workers in the activity (computed as the fraction of native workers with completed vocational training or higher education), and the activity-specific union density to the empirical specification. ${ }^{13}$ As the column shows, overtime work is associated with a statistically significant 23 percent boost in daily pay, and the coefficients of the other two measures take the expected sign but (because of limited

\footnotetext{
${ }^{12}$ We calculated the overtime variable from an auxiliary data source, the Norwegian Wage Statistics, a survey of establishments and their employees conducted annually. The variable measures the fraction of native full-time workers in the activity who received overtime pay during the survey month.

${ }^{13}$ We are indebted to Pål Schøne for giving us the union membership series. The series is computed as the fraction of native workers who deduct union membership fees from their pay check (which is the common way to pay membership fees among Norwegian union members). Although evidence from the US suggests that union density might not be a good proxy for the ability of unions to influence wages (Bratsberg and Ragan, 2002), establishmentlevel evidence from Norway documents a strong relation between union membership shares and individual wages (Barth et al, 2001).
} 
Table 2: Sensitivity analyses

\begin{tabular}{|c|c|c|c|c|c|c|}
\hline & $\begin{array}{l}\text { Corr with } \\
\text { imm share }\end{array}$ & (1) & (2) & (3) & (4) & (5) \\
\hline \multicolumn{7}{|l|}{ Coefficient of } \\
\hline $\ln (1+\mathrm{M} / \mathrm{N})$ & & $\begin{array}{l}-.652 \\
(.231)\end{array}$ & $\begin{array}{l}-.760 \\
(.177)\end{array}$ & $\begin{array}{l}-.719 \\
(.199)\end{array}$ & $\begin{array}{l}-.018 \\
(.127)\end{array}$ & $\begin{array}{l}-.637 \\
(.279)\end{array}$ \\
\hline $\begin{array}{l}\text { Share working } \\
\text { overtime }\end{array}$ & -0.65 & $\begin{array}{c}.231 \\
(.042)\end{array}$ & $\begin{array}{c}.202 \\
(.046)\end{array}$ & & & \\
\hline $\begin{array}{l}\text { Share skilled } \\
\text { workers }\end{array}$ & -0.38 & $\begin{array}{c}.234 \\
(.261)\end{array}$ & $\begin{array}{c}.208 \\
(.321)\end{array}$ & & & \\
\hline $\begin{array}{l}\text { Union } \\
\text { membership }\end{array}$ & -0.54 & $\begin{array}{l}.150 \\
(.140)\end{array}$ & $\begin{array}{l}.232 \\
(.160)\end{array}$ & & & \\
\hline Observations & & 918,082 & 758,359 & 117,759 & 179,015 & 296,774 \\
\hline Individuals & & 217,151 & 179,379 & 22,293 & 34,445 & 56,738 \\
\hline \multirow[t]{2}{*}{ Comment } & & Full sample & Drop road, & \multicolumn{3}{|c|}{ Carpenters, electricians, painters, and plumbers } \\
\hline & & & onduge, tumer & Main activity & $\begin{array}{l}\text { Non- } \\
\text { construction } \\
\text { sector, } \\
\text { placebo } \\
\text { regression }\end{array}$ & $\begin{array}{c}\text { Pooled } \\
\text { sample, with } \\
\text { free vocation } \\
\text { year effects }\end{array}$ \\
\hline
\end{tabular}

Note: Clustered standard errors are reported in parentheses. Sample in column (1) consists of all construction-sector workers; samples in columns (3)-(5) consist of workers with a vocational diploma in one of four narrowly defined fields of study. Regressions control for age (third order polynomial), activity/one-digit industry, and year of observation. Columns (4) and (5) add the immigrant employment share in 3-digit non-construction industries, and column (5) further adds interactions between the control variables and the construction sector as well as separate interaction terms between year and three fields of study. All regressions include individual fixed effects.

variation within activity) are not statistically significant. More important for the present study, however, is that accounting for overtime work, skill composition, and unionization does not affect the estimated coefficient of the immigrant employment variable. Even though each measure is negatively correlated with the immigrant share, conditional on time and activityspecific effects, wage adjustments in the construction sector caused by these factors appear to be orthogonal to those of the immigrant employment share.

We have defined the construction sector broadly and included companies primarily engaged in road, tunnel, and bridge construction in the sector. These activities are characterized by large, 
often public, contracts. Typically, there is a long period between submitting bids and start-up of projects, which might make it more difficult to rely on immigrant labor. As Figure 2 showed, there are relatively few foreign workers in these activities, particularly in road construction. A possible concern, then, is that both wage contracts and immigrant employment dynamics in these activities differ fundamentally from other building activities, and that mixing the two types of activities together influences the estimated relationship between immigration and wages. That is, one might question whether the wage growth of road, tunnel, and bridge construction workers serves as a reasonable counterfactual to what would have happened for carpenters and painters in the absence of immigration. In column (2) we therefore exclude employees of road, tunnel, and bridge construction companies from the wage sample. If anything, this exercise leads to a larger coefficient estimate of the immigrant variable, and there is no support for the notion that the estimated effect of immigration on native wages is an artifact of comparing immigration rates and wage setting of two sectors with widely different institutional arrangements.

The sensitivity analyses in columns (1)-(2) show that our key finding is not driven by failure to account for important observed wage determinants at the activity level. But we cannot rule out that there may be other, unobserved factors that lie behind the less favorable wage growth of construction-sector workers who saw large increases in their activity immigrant employment share. In an influential study from Israel, Friedberg (2001), for example, presents evidence that immigrants disproportionally enter occupations with low wages and that experience low wage growth for other reasons. Ideally, to rule out unobserved factors one would wish to include free year of observation effects by activity in the empirical model specification. Unfortunately, such flexibility would not permit identification of the immigration wage effect as there is only one observation of the immigrant share per activity-by-year cell. A possible solution to this identification problem is to contrast wage developments of construction workers with comparable workers in other industries and thereby account for activity-specific time effects by means of a difference-in-difference-in-difference methodology.

To make such an identification strategy credible, we choose to focus on well-defined groups of workers by educational attainment and extract from our sample those with a vocational diploma in one of four fields of study — carpentry, electrical installation, painting, and plumbing — and 
who are employed in the relevant construction activity. ${ }^{14}$ In column (3) we first verify that these four types of workers share the immigration wage effect of the remainder of the construction sector. The reduced-sample estimate of $\theta,-.719$, is practically identical to our preferred estimate for the full sector (i.e., Table 1, column 2).

We next extract from the payroll data workers in other sectors of the economy with the equivalent educational diplomas. As it turns out, a large number of carpenters, electricians, painters, and plumbers are employed outside the construction sector in a broad range of industries, including public and private utilities, mechanical manufacturing, wholesale trade, public administration, property management, and so on. As an initial check of whether our main result reflects differential trends, we conduct a placebo experiment by regressing the wages of these non-construction sector employees on the immigrant share taken from the relevant trade in the construction sector. If our findings were driven by positive wage shocks for electricians and plumbers because they, e.g., due to SBTC have benefitted more from technological advances than other construction workers, the coefficient estimate from the placebo regression should be similar to that in the construction sector. Column (4) shows that it is not; the estimate is basically zero and statistically insignificant. ${ }^{15}$

In column (5), we stack the two samples of workers with narrowly defined vocational diplomas, but employed in different sectors of the economy, together in order to identify separate year effects by trade. Note that the model specification also allows for differential year effects for construction and non-construction sector workers, and accounts for differences in business cycle movements across sectors. The source of identification of the immigration wage effect is

\footnotetext{
${ }^{14}$ These diplomas are awarded after two years of secondary education course work and two years of apprenticeship. The four occupation groups are also well represented in other construction activities (particularly in the "general/framing" bracket). We exclude such workers from this robustness check, but results are not sensitive to their inclusion.

${ }^{15}$ Workers in non-construction industries may have been affected by immigrant inflows to their own industry. Indeed, over the sample period the immigrant employment share (measured at the 3-digit industry) in the nonconstruction sample rose from 5.4 to 6.6 percent. But unlike in the construction sector, the change in industry immigrant employment between 1998 and 2005 was similar across vocational groups (e.g., the industry immigrant share for non-construction electricians grew from 4.4 to 5.8 percent and that for carpenters from 5.5 to 7.1 percent). The regressions underlying columns (4) and (5) control for the 3-digit non-construction industry immigrant share, but omitting this variable has little bearing on the estimates reported in the table. In the regression in column (4), the coefficient estimate of the non-construction industry immigrant variable is -.309 (.095). This estimate is, however, likely to be impacted by bias from attenuation (because of missing vocation data for many immigrants, we use the immigrant share in the industry which may not be directly relevant for the narrowly defined vocations making up the sample).
} 
therefore the immigrant-induced labor supply shock that is specific to the construction activity, conditional on general wage adjustments for workers in the same trade. As the column shows, allowing for differential wage trends leads to a slightly lower estimate (and boosts the standard error) of the construction-sector immigration wage impact, but the estimate remains negative and significantly different from zero. In conclusion, accounting for separate yearly wage shocks for carpenters, electricians, painters, and plumbers does not appreciably influence our key parameter estimate. There is no indication that the negative estimate of the immigration wage effect is the consequence of failure to account for unobserved factors causing differential wage growth across groups of workers.

\subsection{Labor Market Status of Leavers in 2005}

Results so far point to a strong relation between immigrant entry and native exit from construction activities. To shed further light on this relationship, we next address the structure of exits from the sector. In Table 3 we consider the sub-sample of native workers who were employed in the sector prior to 2001, and examine their labor market status as of 2005 (excluding those who died or turned 67 during the interim years). Twenty-seven percent of these workers had left construction by 2005. That year, one half of the leavers were employed in a new job elsewhere, close to 36 percent received some form of welfare benefit, and the remaining 14 percent had no registered labor income or welfare transfers. The upper panel of the table lists the marginal effects from a multinomial probit regression of employment/welfare status in 2005 on individual and activity characteristics. In the regression, the reference status is continued employment in the construction sector. The association between the immigrant share and the exit probability differs across the three transitions. While we find no significant coefficient of the immigrant share for job changes, workers are significantly more likely to leave employment the higher is the immigrant employment share in their activity. According to the estimates in the first row, a one percentage point increase in the immigrant share is associated with a 0.20 percentage point boost in the transition rate to welfare and a 0.15 percentage point higher rate of transition to the residual state ("other," column 3). Table 3 also lists the coefficient estimates for key individual characteristics, including educational attainment, whether the educational field 
Table 3: Status of leavers in 2005, multinomial probit results

\begin{tabular}{lccc}
\hline Coefficient of: & $\begin{array}{c}\text { Welfare } \\
(1)\end{array}$ & $\begin{array}{c}\text { New job } \\
(2)\end{array}$ & $\begin{array}{c}\text { Other } \\
(3)\end{array}$ \\
\hline Immigrant share & .197 & -.121 & .146 \\
& $(.077)$ & $(.148)$ & $-.021)$ \\
& -.014 & .020 & $(.001)$ \\
Years of schooling & $(.001)$ & $(.001)$ & -.022 \\
& -.050 & -.079 & $(.002)$ \\
Main education field & $(.002)$ & $(.006)$ & -.024 \\
& -.070 & -.007 & $(.003)$ \\
Fixed individual wage & $(.007)$ & $(.013)$ & 3.7 \\
& & & 13.8
\end{tabular}

Note: Listed coefficients are marginal effects $\left(\mathrm{dq}_{\mathrm{ki}} / \mathrm{dx}_{\mathrm{i}}\right)$, where $\mathrm{q}_{\mathrm{k}}$ denotes the probability of outcome $k$. Clustered standard errors are reported in parentheses. Observation count is 164,943 . The sample is restricted to natives with construction employment before 2001 who were below 67 years of age and not deceased in 2005 . The omitted category consists of those who remained in the sector after 2001 (73.1 percent of sample). The "welfare" category includes those who left the sector and received permanent disability (24.2 percent of welfare recipients), rehabilitation (22.2 percent), unemployment (21.8 percent), long-term sick leave (18.7), or other benefits; "new job" consists of those with registered employment outside the construction sector (and who did not receive welfare benefits in 2005); and the "other" category is made up of individuals with some source of non-wage income (82.9 percent), living abroad (11.9 percent), or not identified in the 2005 welfare, employment, income, or migration registers. The fixed individual wage component is predicted from the fixed-effects wage regression in Table 1, column (2). Regression also controls for age (third order polynomial), gender, and year of observation.

matches the activity, ${ }^{16}$ and, to proxy for other labor market skills, the individual fixed wage component (predicted from the fixed-effects wage regression reported in Table 1). The results reveal that employees with low educational attainment and a low individual wage component are more likely to transition out of employment (to welfare or elsewhere) than are other workers. Job mobility to other sectors is more likely for highly educated employees and for those with nonmatching educational qualifications. Note also that there is no significant association between job change and the individual wage component in the data. All in all, the exit structure displayed in Table 3 supports the explanation that selective mobility out of the construction sector explains the bias in the conventional estimate of the impact of immigration on native wages disclosed above.

\footnotetext{
${ }^{16}$ The "main educational field" variable is defined from the two-digit level/field code given in the (six-digit) attainment variable drawn from the education register.
} 
In sum, the empirical analyses of immigration and wages of native construction workers show that the conventional estimator imparts positive bias in coefficient estimates. Further, immigration is associated with selective exit of native workers: As the immigrant employment share goes up within a construction activity, it is the lowest paid natives that tend to leave. Although we are unable to conclude that there is a causal link between immigration and exit of construction workers with low wage potential, the empirical evidence firmly documents a correlation between the two. And it is this correlation that causes the bias in the conventional estimator and masks the true impact of immigration on relative wages.

\section{Wage Effects and Substitutability}

\subsection{The Constant Elasticity of Substitution (CES) Technology}

It has become common practice in the literature to interpret wage effects of immigration within a stylized model with labor demand equations derived from a nested CES production function (Bowles, 1970)

$$
Q_{t}=\left[\sum_{j=1}^{J} \lambda_{j t} L_{j t}^{\rho}\right]^{1 / \rho},
$$

where $L_{j t}$ is a composite labor input of type $j$ in period $t$ and $\lambda_{j t}$ denotes the efficiency of the input. As in Ottaviano and Peri (2006), we write the composite labor input as a CES combination of native and immigrant labor,

$$
L_{j t}=\left[N_{j t}^{\pi}+\varphi_{j t} M_{j t}^{\pi}\right]^{1 / \pi}
$$

The parameters $\rho$ and $\pi$ reflect the degree of substitution between and within labor types; $\rho=1-\sigma_{J}^{-1}$ where $\sigma_{J}$ is the elasticity of substitution between types, and $\pi=1-\sigma_{M}^{-1}$ where $\sigma_{M}$ is the elasticity of substitution between immigrants and natives within type. As such, this specification allows for imperfect substitution between immigrants and natives within labor type $(-\infty<\pi \leq 1)$. The relative productivity of immigrant labor is measured by $\varphi_{j t}$, where $0<\varphi_{j t} \leq 1$. 
In a competitive labor market where the wage of the labor input equals its marginal product, we have

$$
W_{j t}^{N}=Q_{t}^{1-\rho} \lambda_{j t} L_{j t}^{-(\pi-\rho)} N_{j t}^{-(1-\pi)}
$$

for natives, and

$$
W_{j t}^{M}=Q_{t}^{1-\rho} \lambda_{j t} L_{j t}^{-(\pi-\rho)} \varphi_{j t} M_{j t}^{-(1-\pi)}
$$

for immigrants. Consider first the native wage impact of an immigration-induced increase in the composite labor input, holding native employment $\left(N_{j t}\right)$ constant and ignoring any effect through production $\left(Q_{t}\right)$ common to all labor types,

$$
\frac{d \ln W_{j t}^{N}}{d \ln L_{j t}}=-(\pi-\rho)=-\left(\frac{1}{\sigma_{J}}-\frac{1}{\sigma_{M}}\right) .
$$

If immigrants and natives are perfect substitutes (i.e., $\sigma_{M}=\infty$ ), the native wage adjustment following an increase in immigration is simply given by the negative of the inverse of the elasticity of substitution across labor types. In other words, in this case the wage adjustment depends only on substitutability of labor across types, with smaller wage adjustments the easier it is to substitute for other types of labor. The expression also shows that, in general, the native wage adjustment is less responsive to immigration when immigrants and natives are imperfect substitutes, a result highlighted in recent contributions by Ottaviano and Peri (2006), Manacorda et al (2007), and Card (2009). As in Peri and Sparber (2009), imperfect substitutability may result from native task specialization in response to (low-skilled) immigration. Indeed, the effect of immigration on the native wage is negative only if the elasticity of substitution between natives and immigrants within type exceeds that between labor types. The composite labor is not a directly observable entity, however, and the elasticity with respect to immigrant labor (again holding native supply constant and ignoring effects via Q) can be written

$$
\frac{d \ln W_{j t}^{N}}{d \ln M_{j t}}=-\left(\frac{1}{\sigma_{J}}-\frac{1}{\sigma_{M}}\right) \frac{d \ln L_{j t}}{d \ln M_{j t}}=-\left(\frac{1}{\sigma_{J}}-\frac{1}{\sigma_{M}}\right) s_{j t},
$$


where $s_{j t}$ is the wages paid immigrant labor as a share of the total wage bill. ${ }^{17}$

\subsection{Identification of Technology Parameters}

Empirical studies of the immigration wage impact are typically based on aggregated data, e.g., averages computed within education-by-experience cells across time. If the relative efficiency of immigrants within type remains constant over time, and thereby will be captured by type fixed effects in the empirical model, one can back out the elasticity of substitution between immigrants and natives by comparing changes in relative wages and immigrant employment within type, as

$$
\ln \left(\frac{W_{j t}^{M}}{W_{j t}^{N}}\right)=\ln \varphi_{j t}-\frac{1}{\sigma_{M}} \ln \left(\frac{M_{j t}}{N_{j t}}\right)
$$

Changes in relative wages of natives across types are less straightforward to interpret, as

$$
\ln \left(\frac{W_{j t}^{N}}{W_{j^{\prime} t}^{N}}\right)=\ln \left(\frac{\lambda_{j t}}{\lambda_{j^{\prime} t}}\right)-\left(\frac{1}{\sigma_{J}}-\frac{1}{\sigma_{M}}\right) \ln \left(\frac{L_{j t}}{L_{j^{\prime} t}}\right)-\frac{1}{\sigma_{M}} \ln \left(\frac{N_{j t}}{N_{j^{\prime} t}}\right)
$$

Even if we assume type-neutral technological progress, where $\ln \lambda_{j \mathrm{t}}=\ln \lambda_{j}$ for all $t$, there remains a challenge in that we do not observe the relative efficiency of immigrants and therefore the composite labor of each type. Intuitively, observing a large wage differential between groups $j$ and $j^{\prime}$ is consistent both with differences in labor supply measured in efficiency units as well as a limited degree of substitutability.

A central result from the prior section is that immigration can go hand in hand with compositional change of the workforce, demonstrating a pitfall of aggregated data and a need for estimates based on individual panel data. An empirical specification of the native first-order condition written in terms of observable entities $\left(N_{j t}\right.$ and $\left.M_{j t}\right)$ is given by

(3) $\ln W_{j t}^{N}=(1-\rho) \ln Q_{t}+\ln \lambda_{j t}-\left(1-\frac{\rho}{\pi}\right) \ln \left(1+\frac{M_{j t}}{N_{j t}}\right)+\left(\frac{\pi^{2}-2 \pi+\rho}{\pi}\right) \ln N_{j t}-\left(1-\frac{\rho}{\pi}\right) \kappa_{j t}$

${ }^{17}$ The immigrant wage share is $s_{j t}=\frac{W_{j t}^{M} M_{j t}}{W_{j t}^{M} M_{j t}+W_{j t}^{N} N_{j t}}$. Note that $s_{j t}=P_{j t}$ if $W_{j t}^{M}=W_{j t}^{N}$. 
where $\kappa_{j t}=\ln \left(\frac{N_{j t}^{\pi}+\varphi_{j t} M_{j t}^{\pi}}{N_{j t}+M_{j t}}\right)$.

We consider the supply of native and immigrant labor as exogenous. In the empirical model, the common output effect from increased labor supply will be captured by the time fixed effects, and, again, any type-neutral technological progress will be captured by the labor type fixed effects.

In light of this CES structure, our estimated parameter is then ${ }^{18}$

$$
\theta=-\left(1-\frac{\rho}{\pi}\right)=-\frac{1-\left(\sigma_{J} / \sigma_{M}\right)}{\sigma_{J}\left(1-1 / \sigma_{M}\right)}
$$

As this expression shows, the effect of increasing the immigrant share on the wage of natives of labor type $j$ depends on the two substitution parameters, and the direct wage effect is negative if and only if $\sigma_{J}<\sigma_{M}$. ${ }^{19}$ When natives and immigrants are imperfect substitutes, a larger part of the wage adjustment will be absorbed by immigrants who arrived earlier (who in this setup are assumed to be perfect substitutes with newly arrived immigrants).

Further insight can be gained from studying the wages of immigrants across types. For immigrants, the wage equation reads

$$
\begin{aligned}
\ln W_{j t}^{I}= & (1-\rho) \ln Q_{t}+\ln \lambda_{j t}-\left(1-\frac{\rho}{\pi}\right) \ln \left(1+\frac{M_{j t}}{N_{j t}}\right)-(1-\pi) \ln \left(\frac{M_{j t}}{N_{j t}}\right) \\
& +\ln \varphi_{j t}+\left(\frac{\pi^{2}-2 \pi+\rho}{\pi}\right) \ln N_{j t}-\left(1-\frac{\rho}{\pi}\right) \kappa_{j t}
\end{aligned}
$$

and is identical to the expression for the native wage (equation 3) except for two terms. First, wages of immigrants depend on their relative labor efficiency. The identification of substitution parameters requires that efficiency differentials across types are time invariant $\left(\ln \varphi_{j t}=\ln \varphi_{j}\right.$ for

\footnotetext{
${ }^{18}$ Here we ignore the impact via change in $\kappa_{j t}$. Note that $\kappa_{j t}$ will equal zero in the case where immigrant and native labor are equally productive and perfectly substitutable $\left(\varphi_{j t}=1\right.$ and $\left.\pi=1\right)$. In other cases, ignoring $\kappa_{j t}$ will introduce omitted-variable bias towards zero in the coefficient estimate of $\ln (1+M / N)$ as the derivative of $\kappa_{j t}$ with respect to $M_{j t}$ is negative, but the bias will be negligible for values of $\varphi_{j t}$ and $\pi$ close to unity. Intuitively, the variation in observed immigrant shares exaggerates the variation in effective labor supply when $\varphi_{j t}<1$.

${ }^{19}$ In this, we assume that $\sigma_{M}>1$. See the evidence in Jaeger (2007).
} 
all $t$ ) and thereby captured by the labor type fixed effects. Second, the immigrant wage equation contains an additional term with log relative immigrant-native employment multiplied by a nonpositive parameter, $-(1-\pi)$, which is equal to zero only if immigrants and natives are perfect substitutes. By comparing the estimates of $\theta$ for natives and immigrants, we can therefore test the null hypothesis that immigrants and natives are perfect substitutes within labor type. Intuitively, the relative wages of immigrants and natives of the same labor type will not be affected by a labor supply shock (immigration) if the two are perfect substitutes in production. Conversely, if immigrants and natives are imperfect substitutes, labor supply shocks due to immigration will have more severe effects on the wages of immigrants than natives of the same labor type.

\subsection{Empirical Estimates}

The results from regressions where the native wage sample has been augmented with a sample of immigrant wage earners are shown in Table 4. The first two rows report the estimated wage effects for natives and immigrants, comparable to the individual fixed-effects estimate in Table 1, column 2, based on the pooled regression of native and immigrant construction workers. The estimate of -.885 for the immigrant wage is fairly similar, although slightly more negative than that for natives, -.704. Given the precision of the estimates, we are however unable to reject the null hypothesis that the two estimates are equal and that natives and immigrants are perfect substitutes within construction activity. Under perfect substitutability within activity, the estimated coefficient for natives implies an elasticity of substitution between workers in different activities $\left(\sigma_{J}\right)$ of $1.4(=1 / 0.704$; see equation 4$)$.

So far, we have implicitly assumed that workers of different skills are perfect substitutes within labor type. An extension of the CES framework that includes three skill groups allows us to address whether native-immigrant substitutability might differ by skill. For example, if wages of low-skilled immigrant and natives are equally affected by an increase in low-skilled immigrant labor, theory suggests that low-skilled immigrants and natives are perfect substitutes. Missing 
Table 4: Heterogeneous effects of immigration on log wages

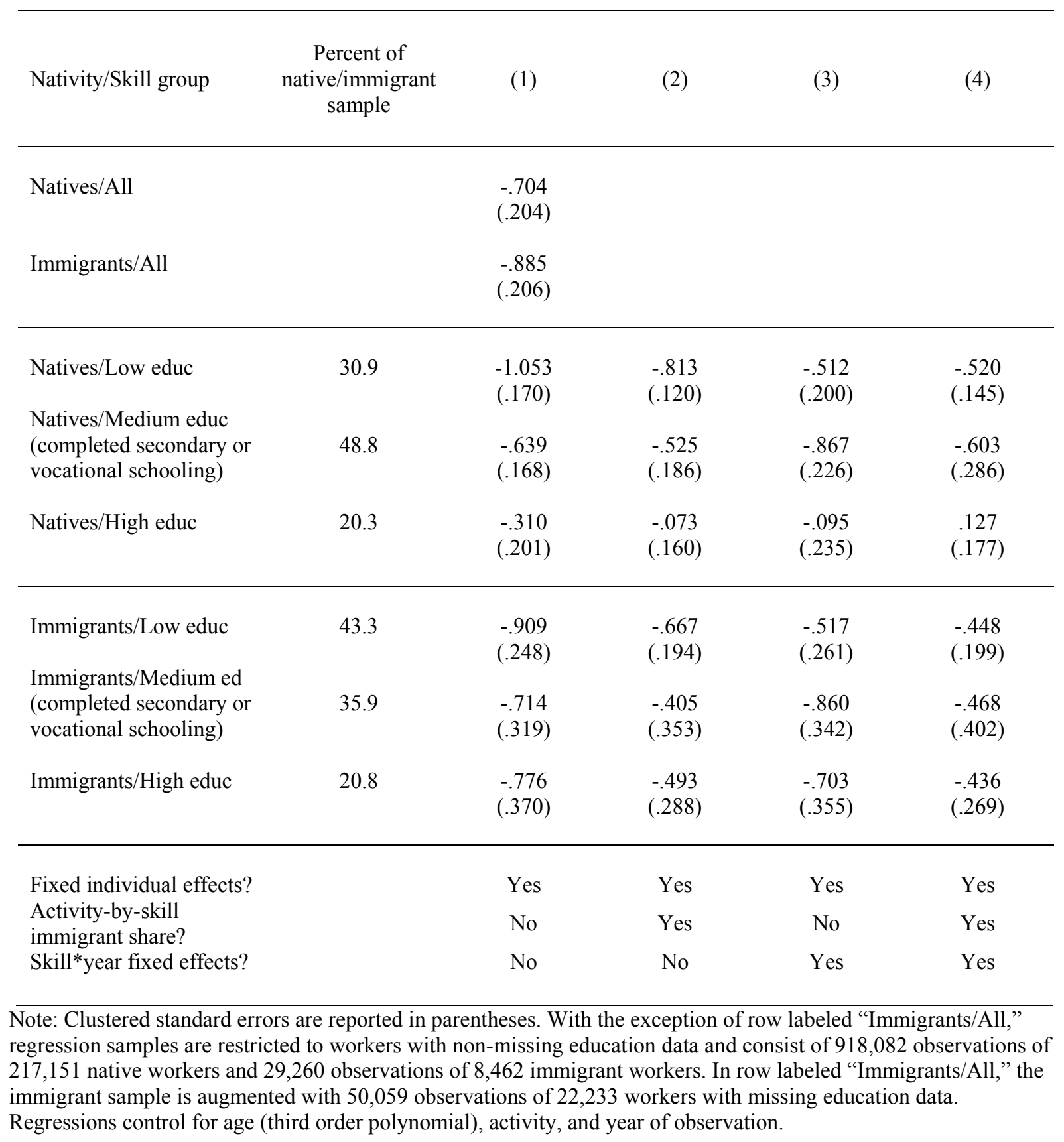


information on educational attainment of many immigrants creates two obstacles to the empirical analysis by skill, however. ${ }^{20}$ First, skill-specific immigrant shares are not directly observable. We have constructed a proxy measure assuming that, for each year and activity, the skill distribution of immigrants with missing education data is the same as that for those with recorded attainment, but we first report estimates using the overall activity immigrant employment share. Second, in the immigrant wage sample, skill-specific effects can only be estimated for workers for whom we have data on educational attainment.

Results from skill-specific estimation of $\theta$ are presented in the lower panels of Table 4. Two empirical patterns stand out from the table. One, for immigrants the wage effects of new immigration are quite similar across skill groups. Regardless of whether we use the activity-wide or the skill-by-activity measure of immigrant employment, or whether or not we allow for greater flexibility of the empirical specification by adding two-way interactions between activity, skill, and year of observation (as in columns 3-4), there are no significant differences in wage effects across immigrant skill groups. Two, for natives the wage effect of immigration is absent for highskilled workers, while, for low and medium skilled, wage effects are very similar to what we find for immigrants with equivalent educational attainment. This suggests that, at least for the latter skill groups, immigrants and natives are close to perfect substitutes. Although estimated with some imprecision, for low and medium skilled workers the estimates of $\theta$ fall in the range -0.9 to -0.5. If immigrants and natives are perfect substitutes $\left(\sigma_{M}=\infty\right)$, the implied range for $\sigma_{J}$ given by equation (4) is 1.1 to 2.0. Among high-skilled construction workers, coefficient estimates are closer to zero for natives than for immigrants, and the evidence points to natives and immigrants being imperfect substitutes within activity. At least within the context of the competitive model, native college graduates appear to be protected by limited substitutability and for this skill group the main impact of immigration is to reduce the wages of immigrants themselves.

\footnotetext{
${ }^{20}$ We collect data on attainment from the education register, where information typically stems from Norwegian educational institutions, supplemented with decennial surveys of the immigrant population. As such, educational attainment is often missing for newly arrived immigrants and in our data for as much as 63 percent of the immigrant wage sample.
} 


\section{Immigration and Prices}

Lower wages reduce production costs. As services in the construction sector are not highly exposed to international competition, theory predicts that domestic prices should fall as a consequence of a reduction in wages when markets are competitive or firms set prices with a markup on unit costs. The cost reduction results both from the reduced wages of incumbent workers (natives and immigrants alike) and the direct contribution from new immigrants with lower pay.

A few recent studies address how immigration affects prices. Lach (2007) argues that, in Israel after the large-scale influx of former Soviet citizens, immigration affected prices by changing the structure of product demand. When product demand of (newly arrived) immigrant households is more elastic than that of natives, due to, e.g., lower search costs and income, retailers will lower their markups the larger is the immigrant consumer base. Cortes (2008) shows that the prices of immigrant-intensive services in the United States fell in response to increases in the low-skilled immigrant labor force. Unlike Lach, Cortes argues that prices declined because the increase in labor supply reduced wages and production costs. In a recent paper, Frattini (2008) studies prices of non-traded services (such as restaurant and bar visits and take-away food) in the United Kingdom and finds that, during the period 1995-2007, price changes for services with a high concentration of low-wage workers were negatively correlated with regional changes in immigration. $^{21}$

In line with the logic of our wage study, we consider price effects by looking at how relative prices for different services within the construction sector have evolved over time. The idea is simple. Unless firms are able to convert all of the benefits from reduced wages and lower costs into profits, relative prices of services that use immigrant labor more intensively should fall. Price information is available from a specific building costs program administered by Statistics Norway. The program collects data and publishes price indices for various services needed for housing construction annually (Statistics Norway, 2006). We are able to match these price indices to eight of the sixteen activities detailed in the prior section, including electrical, plumbing,

\footnotetext{
${ }^{21}$ Immigration may also drive up prices; Saiz (2007) reports evidence that increased immigrant inflows raise rents and housing values in US cities.
} 
Figure 4: Change in immigrant share and annual price growth by activity, 1998-2005

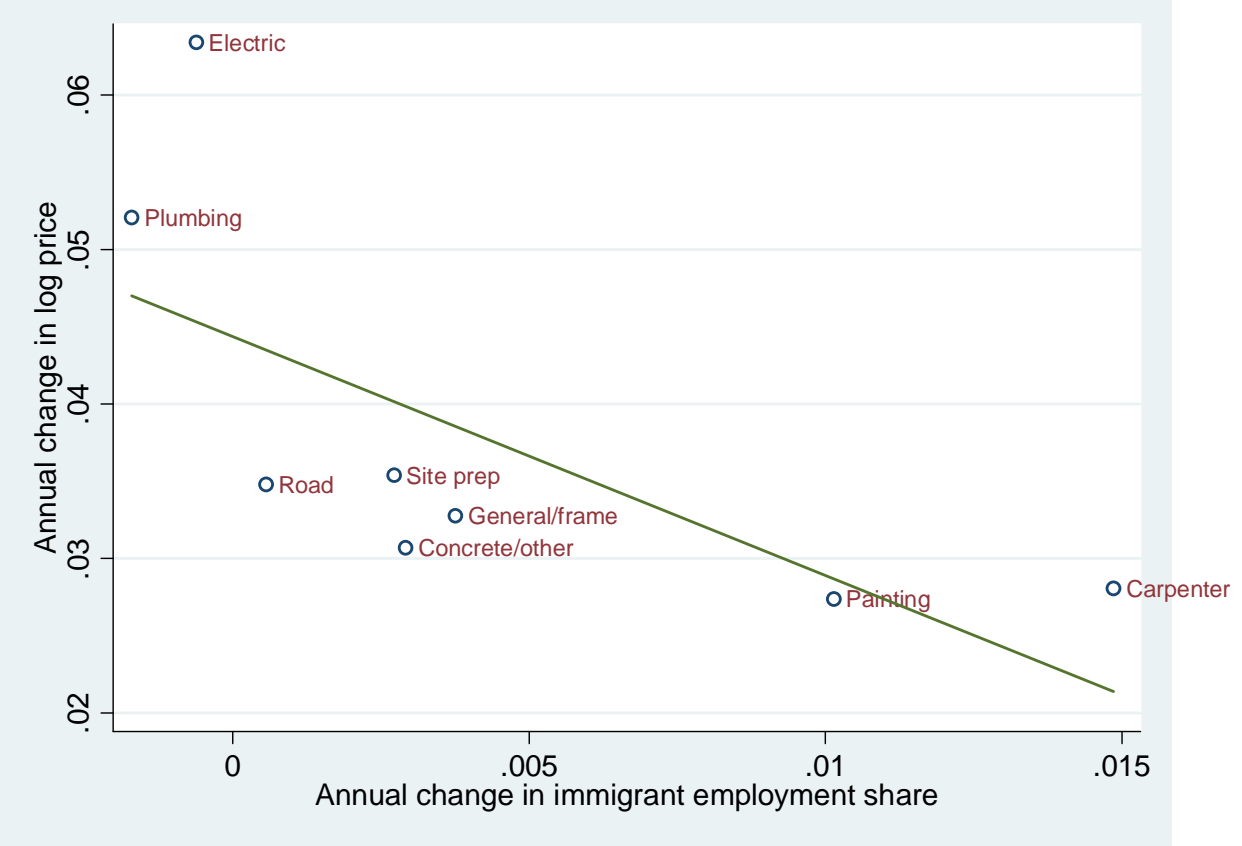

carpenter, and painting services (see Figure 4). The pattern is striking. Over time, the prices of services with no increases in immigrant labor have risen at a rate 50 to 100 percent above that observed for services that intensified their use of immigrant labor.

A regression analysis where the $\log$ price of activity $j$ in year $t$ depends on fixed time and activity effects in addition to the immigrant employment share, i.e.,

$$
\ln Q_{j t}=\delta \ln \left(1+M_{j t} / N_{j t}\right)+\eta_{j}+v_{t}+\zeta_{j t}
$$

provides an estimate of the price effect $(\delta)$ equal to -1.2 (.21); see Table 5, column (1). Evaluated at the mean immigrant employment share in the price dataset (0.095), the estimate implies a price elasticity of -0.11 . In other words, a ten percent increase in immigrant construction labor is predicted to reduce prices of construction services by 1.1 percent. As such, our estimate is below that of Cortes (2008), who concludes that a ten percent increase in (low-skilled) immigrants in the US labor force will decrease prices of immigrant-intensive services by 2 percent. Figure 4 clearly suggests that the price changes of electrical installation and plumbing services are crucial to the estimate. But, even if we exclude these activities from the sample, results show that 
Table 5: Effect of immigration on log price

(1)

(2)

(3)

(4)

\begin{tabular}{lcccc}
\hline Coefficient of $\ln (1+\mathrm{M} / \mathrm{N})(\delta)$ & $\begin{array}{l}-1.155 \\
(.214)\end{array}$ & -1.028 & -.763 & -.387 \\
Observations & 63 & 55 & 55 & $(.088)$ \\
Comment & Full sample & Drop plumbing & Drop electrical & $\begin{array}{c}\text { Drop plumbing } \\
\text { and electrical }\end{array}$ \\
& & & &
\end{tabular}

Note: Regressions control for activity and year of observation.

immigrant inflows to an activity reduce price inflation, see columns (2)-(4). ${ }^{22}$ In general, estimates of the effect of immigration on prices exceed the estimated effects on wages of incumbent workers presented in prior sections. A plausible explanation is that there is an added, direct effect of immigration on production costs and that cost reductions in activities with large increases in immigrant employment are amplified by their use of newly arrived low-wage immigrants.

\section{Conclusions}

Our study confirms the predictions of standard neoclassical theory; the relative wages of a group of workers decline if labor supply of that particular group experiences a positive shift. In the words of Borjas (2003), the labor demand is downward sloping. We find that, in the Norwegian construction sector, the wages of native workers fall by about 0.6 percent if the number of immigrant workers in their activity increases by 10 percent. We also show that the effect of immigration on relative wages is masked by a selective outflow of low-paid native workers. Native workers who leave the construction sector as immigrant employment intensifies often leave the labor force. We do not uncover evidence that mobility to jobs outside construction

\footnotetext{
${ }^{22}$ It should be noted that the price indices used for this analysis are largely cost-based. The indices are not based on observed costs for new housing (as it would be hard to keep the standard fixed), but constructed by means of fixed weights from price indices for materials and labor (however collected from different sources from what is used in the analysis of wages in the present study, including direct cost surveys of suppliers).
} 
relates to immigrant inflows, but find that welfare benefit uptake is more likely for low-paid workers who leave activities where immigrants move in.

Thus, access to individual panel data is crucial for empirical identification of the immigration effect as such data allow for estimation of an individual fixed effects model. Because selective attrition in our data includes workers who leave the labor market all together, longitudinal data would be necessary even in a broader study not limited to one sector of the economy. In the present study, where we focus on one sector in order to ensure that time-series variation in labor demand is similar across activities, identification is strengthened by institutional factors: Licensing and qualification standards limit the inflow of immigrant workers to some activities (like electrical installation and plumbing) and not to others (e.g., painting and carpenter services), thus generating exogenous variation in immigrant employment growth in the data. Our estimated wage effect reflects that wage growth over the sample period relates to change in the immigrant employment share within activity. An extensive set of sensitivity checks, including a differencein-difference-in-difference approach where we account for vocation-specific period effects, debunks the explanation that the finding is driven by differential growth in wages across activities caused by other factors.

Increased immigrant employment has the largest effect on the wages of low and medium skilled native workers. Wages of native workers with (some) college education appear to be unaffected by immigration. For immigrant workers, there are no significant differences in wage effects across skill groups. In fact, estimated wage effects for all groups of immigrant workers are quite similar to those for low and semi-skilled native workers. This pattern is consistent with the interpretation that, for low and semi-skilled workers, immigrants and natives are perfect substitutes within activity.

Finally, we show that immigration also affects prices of services in the construction sector. Our estimates suggest that a ten percent increase in immigrant employment is associated with a 1.1 percent price reduction of services supplied by that activity. In other words, immigration also brings about a considerable increase in consumer's surplus. The result supports the findings of recent studies such as Lach (2007) and Cortes (2008), highlighting the need for including product price effects in an overall analysis of the economic consequences of immigration. Paired with the results from the wage study, the finding further illustrates that, within the native population, labor 
immigration to the construction sector generates winners and losers. While low and semi-skilled workers face competitive pressures on wages and employment, the labor market outcomes of skilled construction workers appear unaffected by immigration-induced increases in labor supply. As consumers they also enjoy more services at lower prices - all of which contribute to the explanation of why highly educated groups tend to be more in favor of liberal immigration policies than less-educated natives (Card et al, 2005; Mayda, 2006; Dustmann and Preston, 2007).

\section{References}

Altonji, J.G., and D. Card (1991), The Effects of Immigration on the Labor Market Outcomes of Less-skilled Natives, in J.M. Abowd and R.B. Freeman (eds), Immigration, Trade, and the Labor Market, Chicago: University of Chicago Press.

Aydemir, A., and G.J. Borjas (2007), Cross-country Variation in the Impact of International Migration: Canada, Mexico, and the United States, Journal of the European Economic Association 5: 663-708.

Barth, E., R. Naylor, and O. Raaum (2001), Union Wage Effects: Does Membership Matter? The Manchester School, 68(3): 259-75.

Barth, E., and T. Ognedal (2008), Limits to Tax Evasion, ESOP Working Paper, Department of Economics, University of Oslo.

Berge, C., H. Næsheim, I. Aukrust, A. Mohamed, and B. Østvedt (2007), Employment and Unemployment among Short-Term Immigrants in Norway, Statistics Norway Reports 2007/19.

Borjas, G.J. (1987), Immigrants, Minorities, and Labor Market Competition, Industrial and Labor Relations Review 40(3): 382-92.

Borjas, G.J. (2001), Does Immigration Grease the Wheels of the Labor Market? Brookings Papers on Economic Activity 32, 2001-1: 69-133.

Borjas, G.J. (2003), The Labor Demand Curve Is Downward Sloping: Reexamining the Impact of Immigration on the Labor Market, The Quarterly Journal of Economics 118(4): 1335-74.

Borjas, G.J. (2006), Native Internal Migration and the Labor Market Impact of Immigration, Journal of Human Resources 41(2): 221-58.

Borjas, G.J. (2009), The Analytics of the Wage Effect of Immigration, NBER Working Paper 14796. 
Borjas, G.J., J. Grogger, and G. Hansson (2008), Imperfect Substitution between Immigrants and Natives: A Reappraisal, NBER Working Paper 13887.

Bowles, S. (1970), Aggregation of Labor Inputs in the Economics of Growth and Planning: Experiments with a Two-Level CES Function, Journal of Political Economy, 78(1): 68-81.

Bratsberg, B., and J.F. Ragan, Jr. (2002), Changes in the Union Wage Premium by Industry, Industrial and Labor Relations Review 56(1): 65-83.

Card, D. (1990), The Impact of the Mariel Boatlift on the Miami Labor Market, Industrial and Labor Relations Review 43(2): 245-57.

Card, D. (2001), Immigration Flows, Native Outflows, and the Local Markets Impacts of Higher Immigration, Journal of Labor Economics 19(1): 22-64.

Card, D. (2005), Is the New Immigration Really So Bad? The Economic Journal, 115: F300-23.

Card, D. (2009), Immigration and Inequality, American Economic Review 99(2): 1-21.Card, D., C. Dustmann, and I. Preston (2005), Understanding Attitudes to Immigration: The Migration and Minority Module of the First European Social Survey, CReAM CDP No 03/05.

Carrington, W.J., and P.J.F. De Lima (1996), The Impact of 1970s Repatriates from Africa on the Portuguese Labor Market, Industrial and Labor Relations Review 49(2): 330-47.

Cortes, P. (2008), The Effect of Low-Skilled Immigration on U.S. Prices: Evidence from CPI Data, Journal of Political Economy 116(3): 381-422.

Dustmann, C., F. Fabbri, and I. Preston (2005), The impact of Immigration on the British Labour Market, The Economic Journal, 115: F324-41.

Dustmann, C., T. Frattini, and I. Preston (2007), A Study of Migrant Workers and the National Minimum Wage and Enforcement Issues That Arise, CReAM/Target Discussion paper.

Dustmann, C., and I. Preston (2007) Racial and Economic Factors in Attitudes to Immigration, The B.E. Journal of Economic Analysis \& Policy 7(1) (Advances), Article 62.

Dølvik, J.E., and L. Eldring (2008), Mobility of Labour from the New EU States to the Nordic Region-Development Trends and Consequences, TemaNord 2008:537, Copenhagen: Nordic Council of Ministers (http://norden.org/pub/velfaerd/arbetsmarknad/uk/TN2008537.pdf).

Dølvik, J.E., L. Eldring, J.H. Friberg, T. Kvinge, S. Aslesen, and A.M. Ødegård (2006), Grenseløst arbeidsliv? Endringer i norske bedrifters arbeidskraftsstrategier etter EUutvidelsen, FAFO-rapport 548.

Frattini, T. (2008), Immigration and Prices in the UK, mimeo, UCL and CReAM, February.

Friedberg, R.M. (2001), The Impact of Mass Migration on the Israeli Labor Market, The Quarterly Journal of Economics 116: 1373-1408. 
Friedberg, R.M., and J. Hunt (1995), The Impact of Immigrants on Host Country Wages, Employment and Growth, Journal of Economic Perspectives, 9(2): 23-44.

Greenwood, M.J., and J.M. McDowell (1986), The Factor Market Consequences of U.S. Immigration, Journal of Economic Literature 24: 1738-72.

Hunt, J. (1992), The Impact of the 1962 Repatriates from Algeria on the French Labor Market, Industrial and Labor Relations Review 45(3): 572-89.

Jaeger, D.A. (2007), Skill Differences and the Effect of Immigrants on the Wages of Natives, mimeo, College of William and Mary, April.

Katz, L.F., and K.M. Murphy (1992), Changes in Relative Wages, 1963-1987: Supply and Demand Factors, The Quarterly Journal of Economics 107(1): 35-78.

Lach, S. (2007), Immigration and Prices, Journal of Political Economy 115(4): 548-87.

LaLonde, R.J., and R.H. Topel (1991), Immigrants in the American Labor Market: Quality, Assimilation, and Distributional Effects, American Economic Review 81: 297-302.

Longhi, S., P. Nijkamp, and J. Poot (2005), A Meta-Analytic Assessment of the Effect of Immigration on Wages, Journal of Economic Surveys 19(3): 451-77.

Manacorda, M., A. Manning, and J. Wadsworth (2007), The Impact of Immigration on the Structure of Wages and Employment, Discussion Paper, CEP, September.

Mayda, A.M. (2006), Who Is Against Immigration? A Cross-Country Investigation of Individual Attitudes toward Immigrants, Review of Economics and Statistics 88(3): 510-30.

Okkerse, L. (2008), How to Measure Labour Market Effects of Immigration: A Review, Journal of Economic Surveys 22(1): 1-30.

Ottaviano, G.I.P., and G. Peri (2006), Rethinking the Effects of Immigration on Wages; NBER Working Paper No. 12497.

Ottaviano, G.I.P., and G. Peri (2008), Immigration and National Wages: Clarifying the Theory and the Empirics, NBER Working Paper No. 14188.

Peri, G. (2008), Immigration Accounting: U.S. States 1960-2006., CReAM, CDP No 05/08, University College London.

Peri, G., and C. Sparber (2009), Task Specialization, Immigration, and wages, American Economic Journal: Applied Economics 1(3): 135-69.

Pischke, S., and J. Velling (1997), Employment Effects of Immigration to Germany: An Analysis Based on Local Labor Markets, Review of Economics and Statistics 79: 594-604. 
Saiz, A. (2007), Immigration and Housing Rents in American Cities, Journal of Urban Economics 61(2): 345-71.

Statistics Norway (2006), Prisindekser for bygg og anlegg, bolig og eiendom 2006, Resultater og metoder, NOS D363.

Statistics Sweden (2010), Statistical Yearbook of Sweden 2010. Stockholm: Statistiska centralbyrån.

U.S. Census Bureau (2009), The Foreign-Born Labor Force in the United States: 2007. American Community Survey Reports. U.S. Department of Commerce, December 2009. 